\title{
THE "BURR" RED CELL AND AZOTAEMIA \\ BY
}

\author{
W. A. AHERNE \\ From the Department of Haematology, Radcliffe Infirmary, Oxford
}

(RECEIVED FOR PUBLICATION SEPTEMBER 3, 1956)

In 1949 Schwartz and Motto described a new poikilocyte which they termed a " burr cell." They characterized it as "a peculiar red cell, measuring about $7.5 \mu$ or less in diameter, and having one or more large spiny projections along its periphery." They found it most often in azotaemia (55 of 75 cases in which the non-protein nitrogen exceeded $70 \mathrm{mg} . \%$ ), and occasionally in gastric carcinoma and bleeding peptic ulcer. They concluded that there was no correlation between the occurrence of burr cells and the level of anaemia or nitrogen retention.

Dacie (1954), on the other hand, describes an essentially similar red cell deformity in states of rapidly progressive renal failure, and contends that its appearance is accompanied, at least in some cases, by a haemolytic anaemia.

It would appear that, apart from these observations, little attention has been given to this relatively common haematological finding. An attempt was therefore made to assess its significance in clinical haematology, with particular reference to states of nitrogen retention.

\section{Methods}

Haemoglobin was estimated as oxyhaemoglobin, using the M.R.C. Grey-wedge photometer (Macfarlane, King, Wootton, and Gilchrist, 1948). Reticulocyte preparations were made by the method of Dacie (1950) and counted by means of the Miller ocular disc (Schneiderman and Brecher, 1950). Platelets were counted by the method of Brecher and Cronkite (1950). Red cell osmotic fragility was tested by a modification of the method of Dacie and Vaughan (1938). Standard procedure was used for the Coombs antiglobulin test. Blood films were made directly from finger-prick or venous blood on carefully cleaned slides and stained with May-Grünwald-Giemsa. Heinz bodies were sought on films stained with brilliant cresyl blue. Urine protein was precipitated by $3 \%$ sulphosalicylic acid and estimated in the M.R.C. Grey-wedge photometer. Red cells and polymorphs in urine were counted in a Fuchs-Rosenthal chamber, and the centrifuged deposit was examined in the usual coverslip preparation. Blood urea was estimated by a modification of the method of Archer and Robb (1925).

Red cell mechanical fragility was tested by the following technique, which is modified from that of Goldbloom, Fischer, Reinhold, and Yi-Yung Hsia (1953).
A turn-table was set up to revolve in a vertical plane. At right angles to it were attached $50 \mathrm{ml}$. tightly stoppered Ehrlenmeyer flasks, each containing three $4 \mathrm{~mm}$. glass beads. Venous blood was taken into heparin, corrected to a haematocrit value of $45 \%$ and thoroughly aerated. Of this $0.5 \mathrm{ml}$. was delivered into an Ehrlenmeyer flask and the turn-table was set rotating at 30 r.p.m. for one hour at room temperature. Meanwhile, $0.1 \mathrm{ml}$. volumes of the same blood sample were delivered into each of two centrifuge tubes, one of which contained $10 \mathrm{ml}$. of $\supset$ ammoniated distilled water, and the other $10 \mathrm{ml}$. of normal saline. The former constituted a standard of $\frac{c}{\omega}$ $100 \%$ haemolysis, and the latter, after gentle centrifugation, a blank. Upon completion of the period of trauma $0.1 \mathrm{ml}$. of the test blood was added to $10 \mathrm{ml}$. of $\mathrm{V}$ normal saline and centrifuged. The supernatant was compared with the standards using a Hilger " spekker" twin-cell photoelectric colorimeter, and mechanical fragility expressed as a percentage derived thus:

$$
\frac{\text { traumatically liberated } \mathrm{Hb}}{\text { total } \mathrm{Hb} \text { of haemolysed sample }} \times 100
$$

By this technique the mechanical fragility of seven normal blood samples ranged from $3.1 \%$ to $5.7 \%$, with a mean of $4.6 \%$.

\section{Case Reports}

The following are typical of the cases in which the burr poikilocyte was most characteristically seen.

Case 1.-W. G. (Reg. No. 223031), a man aged 54, had been " off colour" for the preceding two and a half months, and four weeks before admission he bled excessively after the extraction of several teeth. Malaise $\frac{D}{2}$ then increased and one week before admission he began to complain of tremor and twitching of his limbs and $\mathrm{N}$ of some blurring of vision.

On examination he was pale and there was a notice- $N$ able uraemic fetor oris. Blood pressure was 240/120 N $\mathrm{mm} . \mathrm{Hg}$, and the heart was enlarged to the left. There was grade IV retinopathy and moderate papilloedema. A clinical diagnosis of malignant hypertension with uraemia was made.

Investigations.-The first peripheral blood examination was requested by his general practitioner after the episode of gum-bleeding, and was carried out about one $\vec{D}$ week before admission. Haemoglobin was then $57 \% \frac{?}{\mathbb{0}}$ $(9.9 \mathrm{~g} . \%)$. The film showed anisocytosis and considerable $\stackrel{\mathbb{Q}}{\varrho}$ polychromasia, the former being due to the presence of numerous triangular or crescentic poikilocytes and 8 

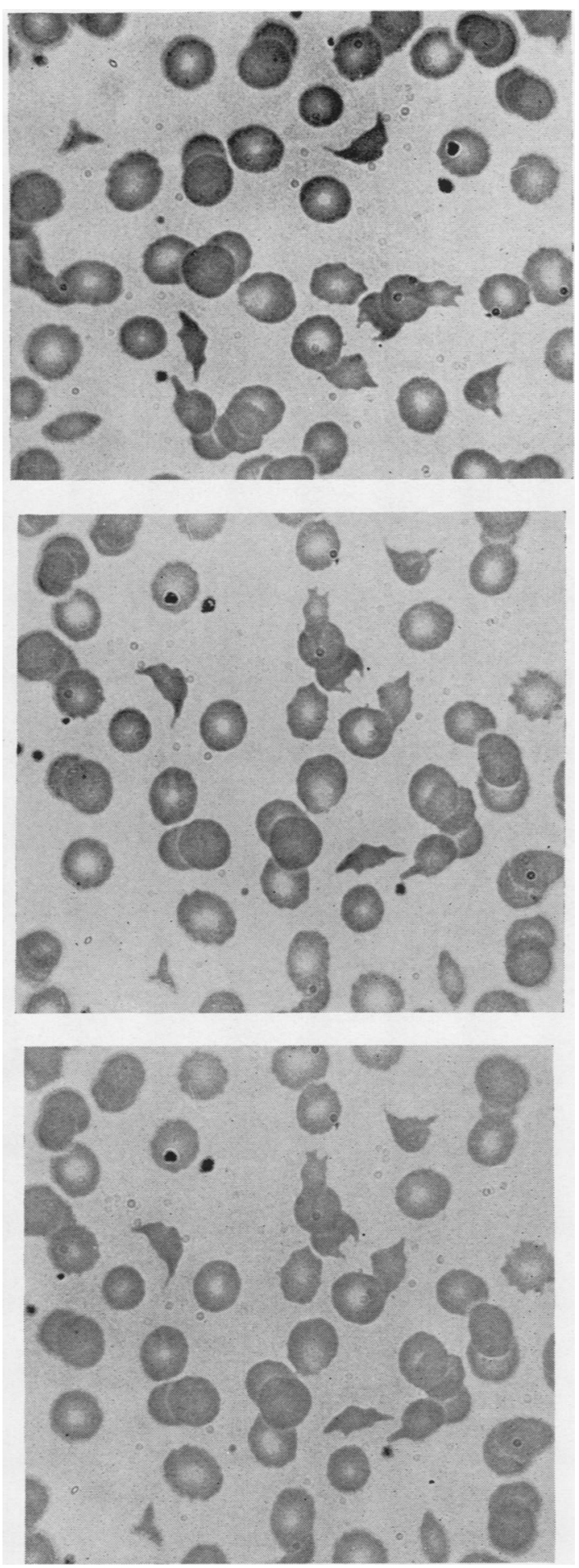

Fig. 1.- C ase 1: triangular and crescentic burr poikilocytes, $\times 1,000$. occasional micro-spherocytes (Fig. 1). It was suggested that these might be uraemic poikilocytes.

On admission the blood urea level was $293 \mathrm{mg} . \%$. Haemoglobin had fallen to $48 \%$ (7.1 g. \%). The film was similar to the previous one in general characteristics, but showed a marked increase in the number of burr poikilocytes.

He was discharged at his own request and died about a week later. Post-mortem examination was not made.

Case 2.-H. K. (Reg. No. 218356), a man aged 66, for one year before admission had complained of severe occipital headache on waking, and for seven months of thirst and polyuria. Eight weeks before admission he had had an episode of coughing accompanied by some haemoptysis, and since then had complained of hiccup. He was admitted one week after the onset of orthopnoea and dyspnoea at rest.

On examination he was dyspnoeic and somewhat distressed. There was noticeable uraemic fetor oris. Blood pressure was 195/140; there was jugular venous congestion, tender enlargement of the liver, and slight ankle oedema.

Investigations.-On admission the blood urea level was $266 \mathrm{mg} . \%$ and the haemoglobin $60 \%(8.9 \mathrm{~g} . \%)$. The film showed numerous burr poikilocytes and increased polychromasia. No Heinz bodies were seen. Four days after admission the haemoglobin was $57 \%$ $(8.4$ g. $\%)$, reticulocytes were $2.3 \%$, and the red cell mechanical fragility was $1.3 \%$. The appearance of the film was unchanged. The next day the blood urea level was $500 \mathrm{mg} . \%$, and the haemoglobin, following transfusion of 3 pints of blood, had risen to $73 \%(10.8 \mathrm{~g} . \%)$. He deteriorated rapidly and died 24 hours later.

Necropsy.-Necropsy showed considerable pulmonary oedema, fibrinous pericarditis, hypertrophy of the left ventricle of the heart, and coarsely granular kidneys.

Microscopy.-Microscopical examination of the kidneys showed chronic pyelonephritis, with collections of polymorphs in some of the tubules, suggesting probable recent exacerbation. The liver and spleen showed wellmarked haemosiderosis, and in the latter organ erythrophagocytosis was visible in places. In a mediastinal lymph node the sinusoids were strikingly dilated and in each of them numerous macrophages could be found engulfing and destroying red cells (Fig. 2). Accompanying these were similar phagocytes containing foamy debris and haemosiderin. A number of red cells lay free in the sinusoids, interspersed with some polymorphs.

Case 3.-P. K. (Reg. No. 215326), a girl aged 10 years, seven days before admission began to complain of sore throat and to have nasal discharge. Two days later she was listless and anorexic. She complained of intermittent abdominal pain and vomited each evening during the next four days. There had been no oedema.

On examination she was pale and there was a petechial rash on both upper thighs, over the front of the chest and left shoulder, and in the left axilla. The tonsils were enlarged and injected. Blood pressure was $140 / 105 \mathrm{~mm}$. $\mathrm{Hg}$ and there was some tender enlargement of the liver. 


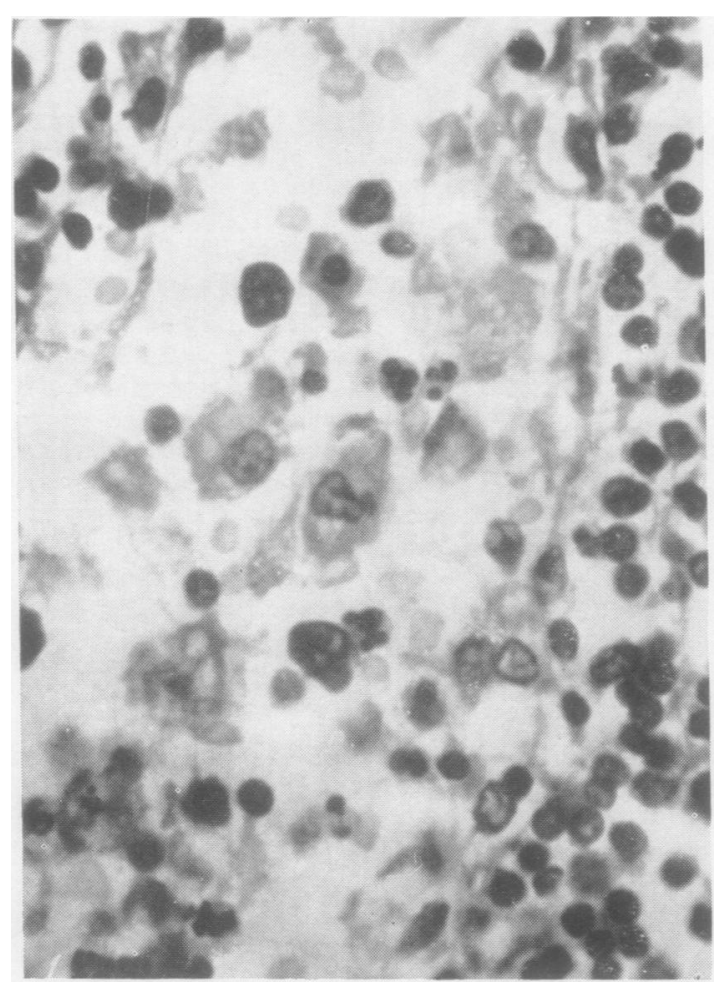

FIG. 2.-Case 2: red cells undergoing phagocytosis in a sinusoid of a mediastinal lymph node. Haematoxylin and eosin, $\times 750$.

Investigation yielded the following results: Blood urea $106 \mathrm{mg} . \%$; urinary protein, $640 \mathrm{mg} . \%$; urine deposit, occasional red blood cells and very occasional granular casts.

The haemoglobin on admission was $70 \%(10.4 \mathrm{~g} . \%)$ and the film showed numerous bizarre poikilocytes and occasional microspherocytes. Polychromasia was well marked. Reticulocytes were $8.2 \%$. The Coombs antiglobulin test was negative, and the saline osmotic fragility test gave a curve of normal shape and position. Mechanical fragility of fresh blood was $4.6 \%$, and after sterile incubation for 18 hours was $14.6 \%$. A sample of normal blood tested in parallel gave values of $3.1 \%$ and $10.3 \%$, respectively. If the wider scatter of results following incubation (Goldbloom et al., 1953) is allowed for, it would appear that the mechanical fragility of the test blood was not significantly abnormal. Search for Heinz bodies and siderocytes proved negative and there was no punctate basophilia.

In view of the petechial rash the following investigations were also done: platelets, 92,000 per c.mm. on admission and 47,000 per c.mm. the next day; bleeding time (Ivy), more than 15 minutes at each of three punctures; tourniquet test, negative.

The blood urea level gradually fell from its initial high value on the day of admission to $45 \mathrm{mg} . \%$ a week later. Concurrently the urine cleared and the blood pressure settled to $13075 \mathrm{~mm}$. $\mathrm{Hg}$. The haemoglobin on the third day after admission was $63 \%(9.3 \mathrm{~g} . \%$ ), but from this it rose to $78 \%(11.5$ g. $\%)$ before discharge. During the same period the platelets returned to normal and the distorted red cells gradually disappeared.

Case 4.-E. K. (Reg. No. 213038), a baby girl aged $4 \frac{1}{2}$ months, during the three weeks before admission had had three bouts of diarrhoea, with occasional vomiting. Her eyelids became puffy and her ankles " thick," but her mother had noticed no urinary abnormality during this period.

On examination there was moderate oedema of both eyelids and slight oedema of the ankles. Blood pressure was $14090 \mathrm{~mm}$. $\mathrm{Hg}$. Temperature was $103^{\circ} \mathrm{F}$. She cried when the renal areas were palpated.

Investigations. - The blood urea level was $187 \mathrm{mg} .{ }^{\prime \prime}$, urinary protein $1,000 \mathrm{mg} . \%$, and in the urine 690 red cells per c.mm., 10 pus cells per c.mm., and occasional granular and hyaline casts were present.

The haemoglobin on admission was $65 \%\left(9.6\right.$ g. $\left.{ }_{0}^{0}\right)$ and the film showed strikingly pleomorphic red cells (Figs. 3 and 4). The majority of the abnormal forms were triangular or crescentic poikilocytes of various sizes: the remainder were spherocytes or spherical fragnients. There was well-marked polychromasia. The following day the haemoglobin was $60 \%(8.9 \mathrm{~g} . \%)$ and reticulocytes were $3 \%$. The appearance of the film was unchanged. There were no Heinz bodies, siderocytes, or punctate cells. Platelets were within normal limits Unfortunately mechanical and osmotic fragility tests could not be carried out.

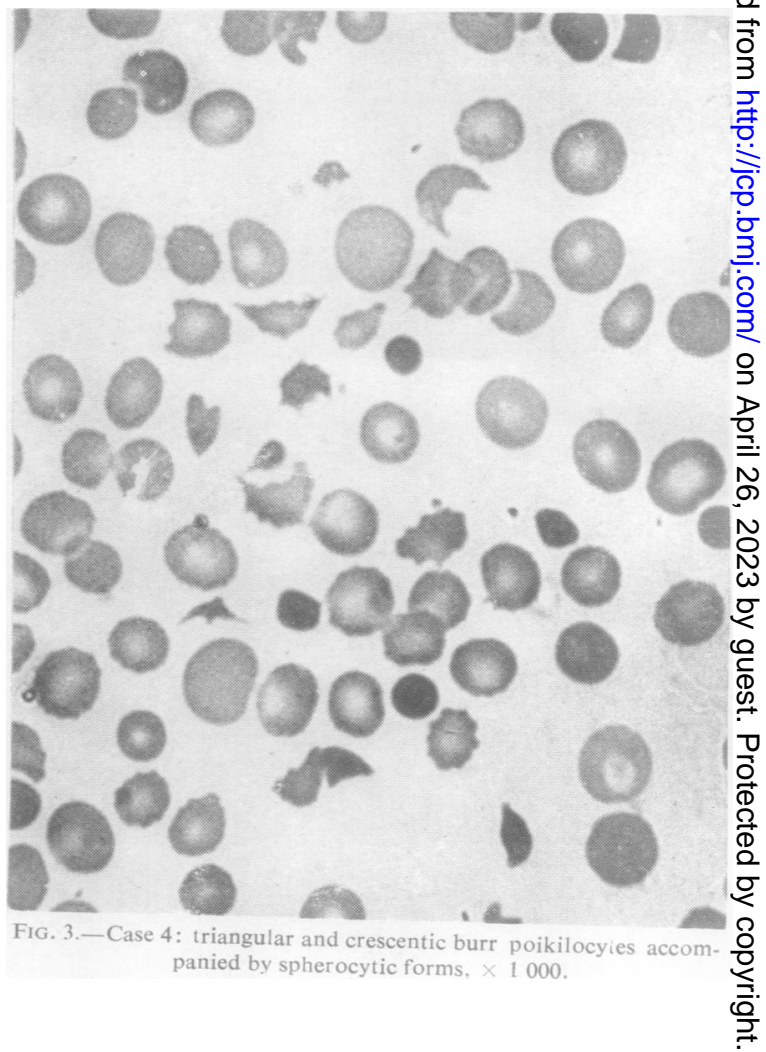



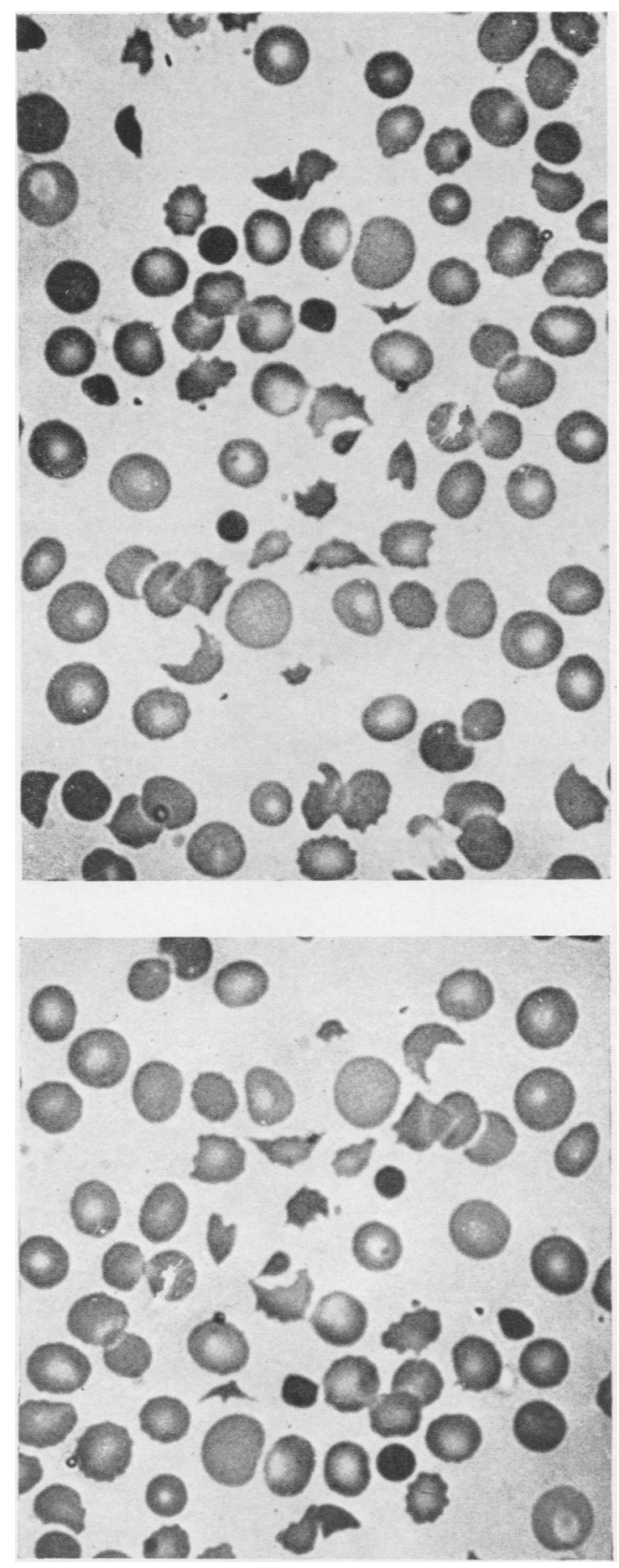

Fig. 4.-Case 4: triangular and crescentic burr poikilocytes accompanied by spherocytic forms, $\times 1,000$.
On the third day after admission the urinary protein had fallen to $360 \mathrm{mg} . \%$, and there were only occasional red cells in the deposit and a few hyaline casts. The blood urea had fallen to $151 \mathrm{mg} . \%$, and continued to fall steadily to $51 \mathrm{mg} . \%$ at the beginning of the fourth week. During the same period the haemoglobin rose from $60 \%$ $(8.9 \mathrm{~g} . \%)$ to $90 \%(14.0 \mathrm{~g} . \%)$ and the abnormal red cells gradually disappeared.

\section{Comment}

Cases 1 and 2 illustrate the condition in which burr poikilocytes were most commonly found, namely, in progressive and ultimately fatal renal failure. Observations on other cases suggest that their presence is not correlated with any particular morbid anatomical cause of this failure. In Case 2 reticulo-endothelial haemosiderosis was greater than could be accounted for by transfusion alone, and, taken in conjunction with the slight but definite reticulocytosis, would appear to indicate excessive destruction of red cells. The erythrophagocytosis observed in the mediastinal lymph node is more difficult to interpret, but essentially the same appearances have been described by Muirhead, Jones, Stirman, and Lesch (1953) in dogs rendered uraemic by bilateral nephrectomy. These animals were kept alive by peritoneal dialysis long enough to develop a progressive anaemia which was considered to be haemolytic in nature.

Case 3 shows that the burr poikilocyte is not always a harbinger of death and may be found in association with reversible renal failure. Alternatively, Case 3 may be a non-fatal example of the syndrome described by Gasser, Gautier, Steck, Siebenmann, and Oechslin in 1955, a diagnosis which incidentally would explain the severe thrombocytopenia. In the five cases described by these authors a severe acquired haemolytic anaemia was associated with bizarre poikilocytes very similar to the burr cells described in the present paper. In addition there was microspherocytosis and marked thrombocytopenia. Initial haemoglobinuria was followed by anuria, progressive nitrogen retention, and death from acute renal failure. In each case microscopical examination of the kidney showed bilateral cortical necrosis, thought to be secondary in some way to the haemolytic process. Here, the burr cell, though associated again with renal failure, clearly antedated it and probably differed in pathogenesis from the type of cell described in the present Cases 1 and 2. Neither Case 3 nor Case 4 (which rather resembles the third case of Gasser et al. and may also be an example of this syndrome) were admitted early enough in their illnesses to betray the temporal relationship of burr cell to azotaemia. 


\section{Observations on Other Cases}

In an attempt to discover the stage of nitrogen retention at which burr poikilocytes begin to appear the peripheral blood was examined in 25 azotaemic patients: in many instances serial examinations were made. In nine of these cases the red cells were, to a greater or lesser degree, degraded to bizarre poikilocytes and microspherocytes; in four occasional poikilocytes could be found; and in the remaining 12 there was no particular abnormality. Of the 13 cases showing burr cells, only one had a blood urea level of less than $150 \mathrm{mg} . \%$ and this was an isolated reading. Of the 12 remaining ones, four had blood urea levels above $150 \mathrm{mg} . \%$; two spiked sharply to $475 \mathrm{mg} . \%$ and $590 \mathrm{mg} . \%$ and fell again promptly; two were isolated readings of $197 \mathrm{mg} . \%$. In general, then, the burr poikilocyte may not be expected in significant numbers until the blood urea is in the region $175-200 \mathrm{mg} . \%$.

Where serial estimations of blood urea were available a second characteristic became apparent. These cases tended to segregate into two groups: one in which the blood urea rose steadily over a number of days, and the other in which it fluctuated irregularly. Positive cases showed a strong tendency to occur in the former group and negative in the latter. All of the nine patients in whom poikilocytosis was conspicuous belonged to the former group: eight of these died, three of chronic nephritis, three of chronic pyelonephritis, one of polycystic kidneys, and one of malignant hypertension. The surviving patient had acute retention of urine due to benign prostatic hypertrophy. In effect then the burr poikilocyte is fairly closely correlated with fatal uraemia, though, as has been indicated, it is not invariably so and should be considered a grave prognostic omen.

Post-mortem examination was carried out on 11 members of this whole series. Of these, seven had shown well-marked poikilocytosis during their last illness. The remaining four had had raised blood urea levels but minimal red cell changes. Macroscopically, neither liver nor spleen was remarkable in either group, but microscopically both organs showed marked haemosiderosis in all of the seven cases showing burr cells and unequivocal erythrophagocytosis in five of these. Two cases had had small transfusions which were considered insufficient to account for the observed degree of haemosiderosis. Of the four other cases mild haemosiderosis was present in two and none showed erythrophagocytosis. Bone marrow, unfortunately, was not available.

The accepted explanation for the anaemia of progressive renal failure postulates marrow depres- sion by some retained toxic metabolite. Callen and Limarzi (1950) reviewed the peripheral blood and bone marrow findings in 102 cases of renal disease and came to this traditional conclusion. They had difficulty, however, in accounting for the fact that $80 \%$ of their cases showed marrow hyperplasia where hypoplasia might have been expected, and then were led to suppose some inhibition of red cell release. They stated that "rarely, and perhaps transiently, the bone marrow may undergo stimulation and be associated with a slight reticulocytosis in the circulating blood."

Although reticulocyte counts were available in only four cases of the present series $(2.3 \%, 3.7 \%$, $3.0 \%$, and $8.2 \%$ ), well-marked polychromasia was usually seen to accompany burr poikilocytosis. Taken in conjunction with the observed degree of reticulo-endothelial haemosiderosis and the frequent finding of erythrophagocytosis this would appear to suggest a haemolytic rather than a dyshaemopoietic anaemia.

The Pathogenesis and the Properties of Burr Poikilocytes.-Certain simple questions having a possible bearing on the pathogenesis and properties of "burr" poikilocytes were investigated by the following experiments.

Incubation of Normal Red Cells with Urea Solutions.-Ponder and Ponder (1954) showed that suspension of red cells in falling concentrations of urea from $110 \mathrm{~g} . / 100 \mathrm{ml}$. (saturated) to $13 \mathrm{~g} . / 100 \mathrm{ml}$. caused their immediate fragmentation into pleomorphic daughter cells. These experiments were repeated here with similar results. The fragmented cells, however, could not be said to resemble burr poikilocytes, and the effect could not be obtained with concentrations of urea less than $10 \mathrm{~g} . / 100 \mathrm{ml}$. which, of course, is 20 times the highest value encountered clinically. Similarly, no specific effect could be obtained by incubating red cells in uraemic plasma.

Incubation with Urea Followed by Trauma.Might the trauma of the circulation induce the observed changes in cells which had been damaged by urea or other retained metabolite ? To test this hypothesis washed normal red cells were suspended (a) in normal plasma to which urea had been added to make a final concentration of $350 \mathrm{mg} . \%$ and (b) in uraemic plasma. After 18 hours' incubation the samples were subjected to the trauma of rolling glass beads as in the technique of estimating mechanical fragility. Films were then made and stained with May-Grünwald-Giemsa. No poikilocytes could be found. Moreover, the mechanical fragility of such preparations appeared to be normal, though colorimetric estimations were not made. 
Behaviour of Burr Poikilocytes in Albumin Solutions.-It is established that plasma albumin plays an important part in the maintenance of the normal biconcave discoid shape of the red cell. Might this function be disturbed in uraemia ?

Coverslip wet preparations were made of $(a)$ normal red cells suspended in saline, $(b)$ normal red cells suspended in uraemic plasma, both suspensions having been incubated at $37^{\circ} \mathrm{C}$. for the preceding 24 hours. Both preparations showed the sphering change which Furchgott and Ponder (1940) explain by the adsorption to glass of an anti-sphering albumin. The addition of human albumin to both these preparations by capillarity, in concentrations ranging from $12.5 \%$ to $0.7 \%$, caused approximately $90 \%$ of the red cells to resume their normal shape within one minute. When uraemic blood containing burr poikilocytes was submitted to the same procedure similar results were obtained, but it may be significant that the poikilocytes themselves showed no change at any stage. It was felt that they had lost the elasticity of normal red cells.

Mechanical Fragility of "Burr" Poikilocytes.Blood samples from four uraemic patients, by the technique described, gave mechanical fragility values of $2.5 \%, 3.6 \%, 4.6 \%$, and $1.3 \%$, i.e., tending to the lower limit of normal. That the uraemic burr poikilocyte is not a fragile cell is attested by the fact that it was seen on stained films made from blood which had been subjected to the trauma of this test. Saline osmotic fragility was tested in only two cases, and was normal.

\section{Discussion and Conclusions}

It may be that the pathogenesis of the uraemic poikilocyte is a metabolic problem, possibly involving inactivation or deviation of enzyme systems concerned in maintaining the normal structure of the red cell. It seems reasonable to suppose that the anaemia in which these cells feature is caused mainly by their phagocytic removal in the reticuloendothelial system. In this connexion it may be noted that oddly deformed cells, not unlike burr poikilocytes, may be found in patients who have undergone splenectomy for any reason. In fact, the fundamental process in burr poikilocytosis may be an acceleration of a normal mode of degradation of red cells.

The anaemias of sulphonamide sansitivity and phenylhydrazine poisoning, and the "Heinz body" anaemia of premature children, bear some resemblance to the condition under discussion in that all are characterized by red cell degradation and compensatory marrow activity. But in many ways the anaemia of uraemia is a distinguishable entity. The crescentic burr poikilocyte is unlike most other degraded cells. Heinz bodies and siderocytes do not occur. Autohaemolysis is normal in degree. In anaemias characterized by the presence of Heinz bodies the saline osmotic fragility curve is flattened somewhat, cells containing the inclusions being more resistant than normal and those undergoing fragmentation being more fragile. In uraemia the shape and position of the curve are normal. Polychromasic cells, which show coarse punctate change in phenylhydrazine poisoning, are normal in uraemia.

It is important to distinguish the anaemia of progressive renal failure from the acute haemolytic anaemia associated with renal disease which Gasser et al. (1955) describe in children. Both conditions show essentially similar red cell changes: both carry a grave prognosis. There is some evidence, however, that energetic blood transfusion may be life-saving in Gasser's syndrome.

\section{Summary}

An attempt was made to evaluate the significance of the " burr" poikilocyte in clinical haematology. It was found most characteristically as a component of terminal uraemia, though it occurred occasionally in reversible azotaemia. Accordingly, it would appear to be a serious prognostic sign. An essentially similar cell, apparently of different origin, may occur in a treatable acute haemolytic anaemia of childhood.

It is suggested that the anaemia of renal failure may, in some cases at least, be due to the sequestration and breakdown of deformed, inert burr poikilocytes.

My thanks are due to Dr. Rosemary Biggs and Dr. A. H. T. Robb-Smith for valuable advice, help, and criticism, and to Dr. Victoria Smallpeice, Dr. Hugh Ellis, and Dr. F. G. Hobson for access to clinical records.

\section{REFERENCES}

Archer, H. E., and Robb, G. D. (1925). Quart J. Med., 18, 274.

Brecher, G., and Cronkite, E. P. (1950). J. appl. Physiol., 3, 365.

Callen, I. R., and Limarzi, L. R. (1950). Amer. J. clin. Path., $20,3$.

Dacie, J. V. (1950). Practical Haematology. Churchill, London.

(1954). The Haemolytic Anaemias, p. 364. Churchill, London.

- - and Vaughan, J. M. (1938). J. Path. Bact., 46, 341.

Furchgott, R. F., and Ponder, E. (1940). J. exp. Biol., 17, 117.

Gasser, C., Gautier, E., Steck, A.. Siebenmann, R. E., and Oechslin, R.'(1955). Schweiz. med. Wschr., 85, 905.

Goldbloom, R. B., Fischer, E., Reinhold, J., and Yi-Yung Hsia, D. (1953). Blood, 8, 165.

Macfarlane, R. G., King, E. J., Wootton, I. D. P., and Gilchrist, M. (1948). Lancet, 1, 282.

Muirhead, E. E., Jones, F., Stirman, J. A., and Lesch, W. (1953) Amer. J. Physiol., 173, 371.

Ponder, E., and Ponder R. (1954). Acta haemat. (Basel), 12, 282.

Schneiderman, M., and Brecher, G. (1950). Biometrics, 6, 390.

Schwartz, S. O., and Motto, S. A. (1949). Amer. J. med. Sci., 218, 563. 